\title{
Dynamics of a Heterotrophic Dinoflagellate, Protoperidinium divergens, in the South-Eastern Coastal Waters of the Bay of Bengal
}

\author{
Saleha Khan ${ }^{1 *}$, Roksana Jahan ${ }^{2}$, Moin Uddin Ahmed ${ }^{3}$, M. Aminur Rahman ${ }^{4}$, \\ Md. Mahfuzul Haque ${ }^{1}$ and M. Zahangir Alom ${ }^{5}$ \\ ${ }^{1}$ Department of Fisheries Management, Bangladesh Agricultural University, Mymensingh-2202, \\ Bangladesh. \\ ${ }^{2}$ Department of Marine Fisheries and Oceanography, Sher-e-Bangla Agricultural University, \\ Dhaka-1207, Bangladesh. \\ ${ }^{3}$ Sustainable and Inclusive Shrimp Business Promotion Project, Solidaridad Network Asia, Dhaka, \\ Bangladesh. \\ ${ }^{4}$ Department of Fisheries and Marine Bioscience, Jashore University of Science and Technology, \\ Jashore-7408, Bangladesh. \\ ${ }^{5}$ Department of Fisheries, Matshya Bhaban, Dhaka-1000, Bangladesh.
}

\begin{abstract}
Authors' contributions
The work was carried out in collaboration among all authors. All authors read, reviewed and approved the final manuscript.

Article Information

DOI: $10.9734 / A R R B / 2019 /$ v33i630140 Editor(s):

(1) Dr. Manikant Tripathi, Department of Microbiology, Dr. Ram Manohar Lohia Avadh University, India.

Reviewers:

(1) Piyusha Siddhesh Desai, Fisheries College and Research Institute, India.

(2) Fábio Henrique Portella Corrêa de Oliveira, Universidade Federal Rural de Pernambuco, Brazil. Complete Peer review History: http://www.sdiarticle4.com/review-history/53054
\end{abstract}

Original Research Article

Received 01 October 2019

Accepted 05 December 2019

Published 10 December 2019

\begin{abstract}
This research is the first attempt to present temporal distribution of heterotrophic dinoflagellate Protoperidinium divergens and their relationship with diatom and environmental factors in the Maheshkhali channel, south-east coast of the Bay of Bengal, Bangladesh. The initiation of higher abundances of $P$. divergens were observed in October and reached its peak in November when diatoms were the most abundant phytoplankton. Protoperidinium divergens preferred comparatively low temperature from $20-22^{\circ} \mathrm{C}$ and high concentration of phosphate-phosphorus from $31-37 \mu \mathrm{M}$. It had insignificant relationship with nitrate-nitrogen. Lower abundances of $P$. divergens were
\end{abstract}


observed during pre-monsoon and monsoon due to lower abundances of diatom and higher water temperature $\left(>23^{\circ} \mathrm{C}\right)$. Protoperidinium divergens, therefore, were mainly controlled by the availability of diatom abundance at comparatively lower temperature and higher concentration of phosphatephosphorus. This research is important to estimate the potential trophic impact of $P$. divergens in the Maheshkhali channel.

Keywords: Protoperidinium divergens; temperature; phosphate-phosphorus; diatom; Maheshkhali channel.

\section{INTRODUCTION}

Heterotrophic dinoflagellates are prevalent protists in marine environments, which play a vital role as an intermediate link between the microbial loop and higher trophic levels [1,2] and they also have an important role in the carbon cycling and energy flow in the marine planktonic community [3].

Heterotrophic dinoflagellates have been reported to feed on prey such as bacteria, flagellates, diatoms, other dinoflagellates, ciliates and metazoans $[4,5,6]$ that varies from species to species. For instance, $P$. pallidum prefers diatom, while $P$. steinii feed better on both diatoms and dinoflagellates [7]. Protoperidinium cf. divergens can feed on adult copepods, copepod eggs and nauplii [8]. Protoperidinium spp. feed on prey cells by using a pseudopod "veil", called the pallium, to envelop the prey, with subsequent external digestion [4,9]. This feeding adaptation enables Protoperidinium to consume prey as large as or larger than themselves (including chain forming diatoms) [7], and thus they can compete with mesozooplankton for food resources (within the trophic levels). Although there are many studies on feeding habit of Protoperidinium, little is known about the ecologies of species in this genus.

An extensive bloom of Protoperidinium Bergh was observed, for the first time, in the west coast of the Bay of Bengal in 2008 [10]. Heterotrophic dinoflagellates were comprised as high as $80 \%$ (average $59 \%$ ) of total microzooplankton biomass in the Bay of Bengal and the Andaman Sea [11]. Protoperidinium abundance in the region is mainly controlled by food availability and nutrient. For instance, coastal waters especially at the Ganges-Brahmaputra riverine systems support a comparative abundance of diatoms and in turn Protoperidinium population throughout the year [12]. Protoperidinium abundance might have been occurred due to nutrient enrichment during the south-west monsoon and also influenced by moderate wind driven advection during the northeast monsoon [12]. Although, consistent with the Bay of Bengal, heterotrophic and mixotrophic dinoflagellates (i.e. Ceratium furca, C. tripos, C. fusus, Dinophysis caudata, Prorocentrum micans and Gonyaulax polygramma) were also dominant in the Maheshkhali channel [13], there is very few study on a particular dinoflagellate species in the Maheshkhali channel.

This research was undertaken to present the temporal distribution of heterotrophic Protoperidinium divergens and their relationship with diatom and environmental factors in the Maheshkhali channel, south-east coast of the Bay of Bengal. This finding can be used to estimate the potential trophic impact of $P$. divergens in the Maheshkhali channel.

\section{MATERIALS AND METHODS}

\subsection{Study Area}

The present study was carried out in the Maheshkhali channel, situated at the southeastern coast of the Bay of Bengal, Bangladesh (Fig. 1). Three sampling sites were selected at the mouth of this channel. The channel includes Bakkhali River in the north and the Bay of Bengal in the south. The Maheshkhali channel is very important as a large fishing ground and a centre for recreation. Different traditional capture fisheries and commercial shrimp farms have developed around the estuary. This channel considered as highly productive because of excessive nutrients invaded from industrial wastes, agricultural lands, rural and urban sewages and from the adjacent shrimp and bivalve farms, which sometimes induces the growth of many harmful algae [14].

\subsection{Methods}

Water samples were collected from January to December 2002, covering three seasons: monsoon (June-September), post-monsoon (October-January), and pre-monsoon (FebruaryMay). Monthly plankton samples were collected 


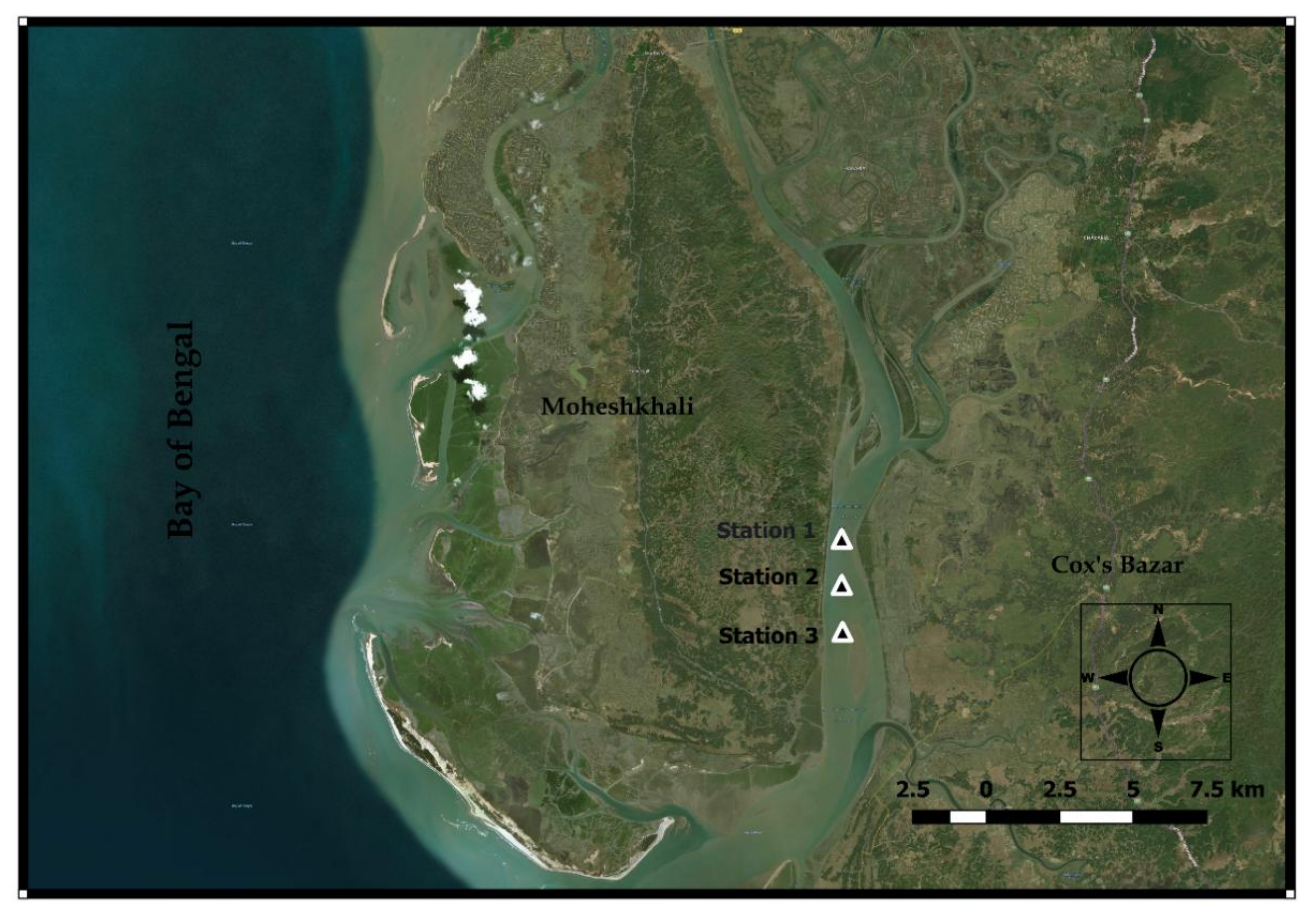

Fig. 1. Map showing the sampling stations in the Maheshkhali channel, south-east coast of the Bay of Bengal, Bangladesh

using a $25 \mu \mathrm{m}$ mesh size net [15]. The samplings were made in during daytime at high tide. For qualitative plankton study a plankton net was towed just under the water surface for one minute at a speed of approximately $1 \mathrm{~m} / \mathrm{s}$. From the net the collected samples were drained in a polyethylene bottle and was preserved with $5 \%$ buffered formalin in sea water. For quantitative study, a known volume (100 liters) of sub-surface water was passed through a plankton net (mesh $25 \mu \mathrm{m}$ ) and the concentrate was collected from the bucket and preserved in 5\% buffered formalin in sea water. The quantitative estimation of phytoplankton was done by Sedgewick-Rafter counting chamber (S-R cell) method using an Olympus binocular microscope. Phytoplankton were identified up to species level as possible and enumerated. Taxonomic study was based on Newell and Newell [16], Taylor et al. [17] and Steidinger and Tangen [18].

During sampling, surface water temperature and salinity were determined using a Celsius thermometer and a Handheld Refractometer, respectively. Nitrate-nitrogen $\left(\mathrm{NO}_{3}-\mathrm{N}\right)$ and phosphate-phosphorus $\left(\mathrm{PO}_{4}-\mathrm{P}\right)$ concentration were measured in the laboratory by $\mathrm{HACH}$ kit (DR 2010). Difference between different groups were analyzed by one-way ANOVA with LSD
(Least Significant Difference) at significance level $p=.05$ using SPSS. Principal component analysis (PCA) was done to elucidate relationships between phytoplankton (i.e. Protoperidinium divergens and diatom) and environmental parameters (i.e. temperature, salinity, nitratenitrogen and phosphate-phosphorus) by Rlanguage using "vegan" and "ggplot2" packages. Stepwise multiple linear regression was performed by IBM-SPSS Statistics 21.

\section{RESULTS AND DISCUSSION}

\subsection{Results}

Comparatively higher abundance of Protoperidinium divergens were observed during post-monsoon (Fig. 2). The cell density started to increase in October $\left(28 \times 10^{3} \pm 8.46 \times 10^{3}\right.$ cells I $\left.^{-1}\right)$ showed the peak $\left(66.14 \times 10^{3} \pm 26.65 \times 10^{3}\right.$ cells $I^{-}$ $\left.{ }^{1}\right)$ in November and again decreased $\left(14.92 \times 10^{3}\right.$ $\pm 2.47 \times 10^{3}$ cell $I^{-1}$ ) sharply in the next month December (Fig. 2). Comparatively low abundances of $P$. divergens were observed during pre-monsoon (mean $2.66 \times 10^{3} \pm 2.23 \times 10^{3}$ cells $I^{-1}$ ) and monsoon (mean $5.22 \times 10^{3} \pm$

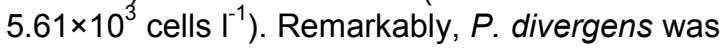
absent in June. On the other hand, the initiation of higher abundance of diatom were observed 
from May that was gradually increased on consecutive months and showed its peak $\left(2002.67 \times 10^{3} \pm 128 \times 10^{3}\right.$ cells $\left.\left.\right|^{-1}\right)$ in November (Fig. 2).

Protoperidinium divergens showed inverse relation with temperature. For instance, comparatively lower temperature was recorded in October $\left(21.17 \pm 0.76^{\circ} \mathrm{C}\right)$ and November $(20.83$ $\pm 0.29^{\circ} \mathrm{C}$ ) during higher abundance period of $P$. divergens (Fig. 3A). In contrast, comparatively high temperature were recorded in August (31.67 $\left.\pm 0.24^{\circ} \mathrm{C}\right)$, September $\left(29.67 \pm 0.24^{\circ} \mathrm{C}\right)$ and April $\left(29.83 \pm 0.24^{\circ} \mathrm{C}\right)$ during low abundance period of $P$. divergens. Higher abundance of $P$. divergens was observed at salinity $13.67 \pm 1.5$ in October and the peak abundance in November at salinity $25.67 \pm 0.24$ (Fig. 3B). It can be noted here that, $P$. divergens was absent at the intermediate level of salinity $(26.6 \pm 0.41)$ in June and the lowest

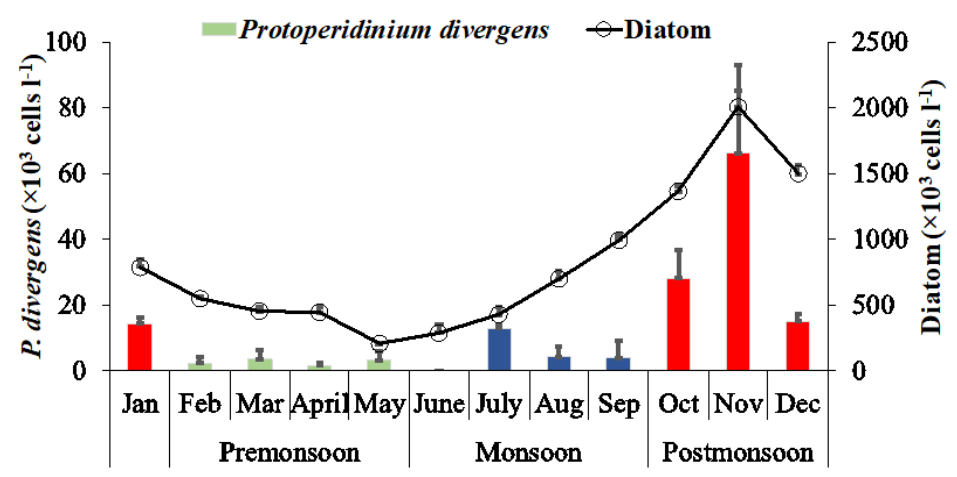

Fig. 2. Temporal distribution of Protoperidinium divergens and diatom abundances from January to December in the Maheshkhali channel

(A)

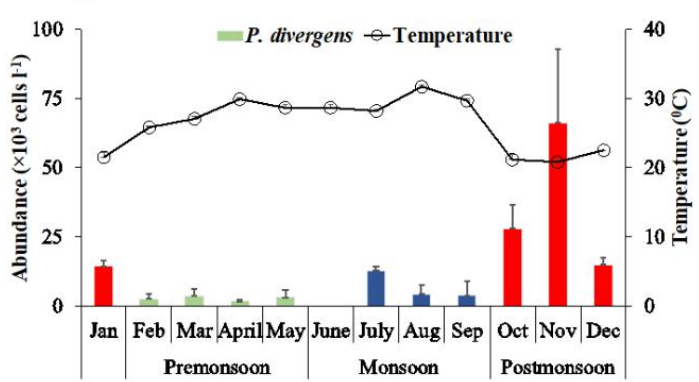

(C)

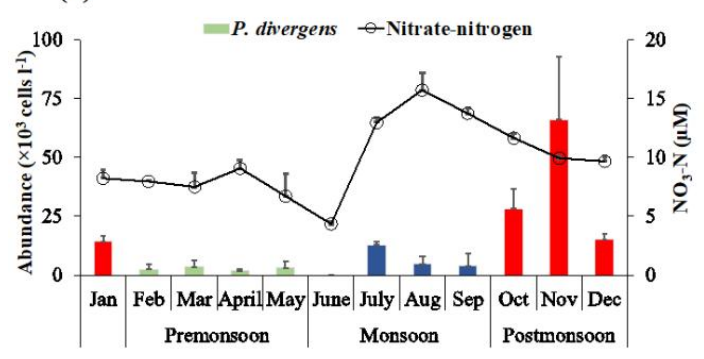

(B)

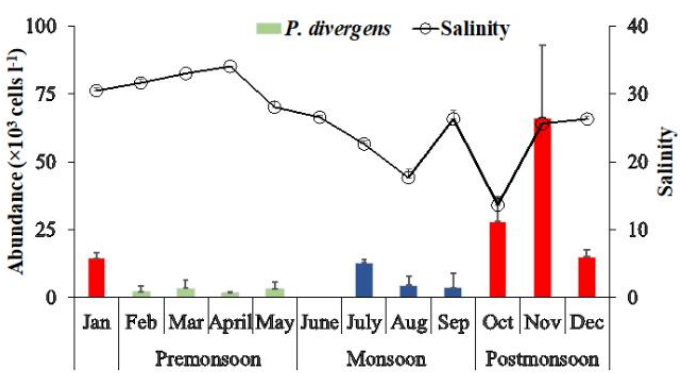

(D)

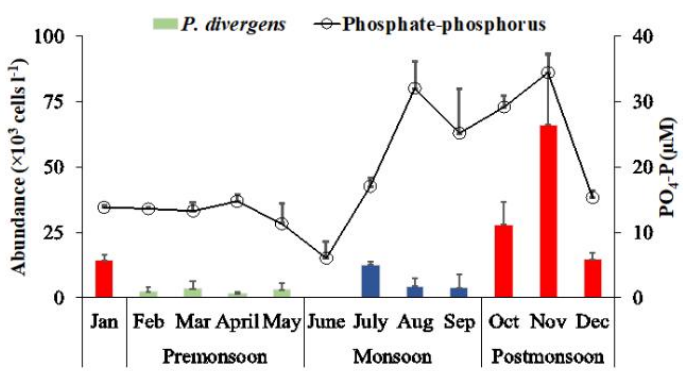

Fig. 3. (A) Temporal distribution of Protoperidinium divergens abundances and temperature from January to December in the Maheshkhali channel. (B) Temporal distribution of $P$.

divergens abundances and salinity from January to December in the Maheshkhali channel. (C) Temporal distribution of $P$. divergens abundances and nitrate-nitrogen from January to

December in the Maheshkhali channel. (D) Temporal distribution of $P$. divergens abundances and phosphate-phosphorus from January to December in the Maheshkhali channel 
abundance was observed at the highest salinity 34 in April. Although comparatively higher concentration of nitrate-nitrogen $(9.89 \pm 0.15 \mu \mathrm{M})$ was observed during high abundance period of $P$. divergens in November, the highest concentration of nitrate-nitrogen $(15.7 \pm 1.47 \mu \mathrm{M})$ was recorded during lower abundance phase of $P$. divergens in August (Fig. 3C). The highest peak of phosphate-phosphorus value was found in November $(34.43 \pm 2.98 \mu \mathrm{M})$ during high abundance period of $P$. divergens, the second peak of phosphate-phosphorus (32 \pm 4.2 $\mu \mathrm{M}$ in August) was unable to enhance $P$. divergens abundance (Fig. 3D). The lowest concentration of phosphate-phosphorus was recorded in June $(6.11 \pm 2.44 \mu \mathrm{M})$ during early monsoon.

Higher abundance of $P$. divergens $\left(30.85 \times 10^{3} \pm\right.$ $25.36 \times 10^{3}$ cells $I^{-1}$ ) was shown at comparatively low water temperature $\left(20-22^{\circ} \mathrm{C}\right)$ that was significantly different than the abundance at temperature range of $23-26^{\circ} \mathrm{C}\left(1.74 \times 10^{3} \pm\right.$ $1.9 \times 10^{3}$ cells $I^{-1}, p=0.003$ ) (Fig. 4A). There was no significant difference between the $P$. divergens abundance at higher temperature range of $27-29^{\circ} \mathrm{C}\left(5.5 \times 10^{3} \pm 5.1 \times 10^{3}\right.$ cells I $\left.^{-1}\right)$ and $30-32^{\circ} \mathrm{C}\left(2.67 \times 10^{3} \pm 2.9 \times 10^{3}\right.$ cells $\left.\mathrm{I}^{-1}, p=0.755\right)$. During the study period, $P$. divergens shown
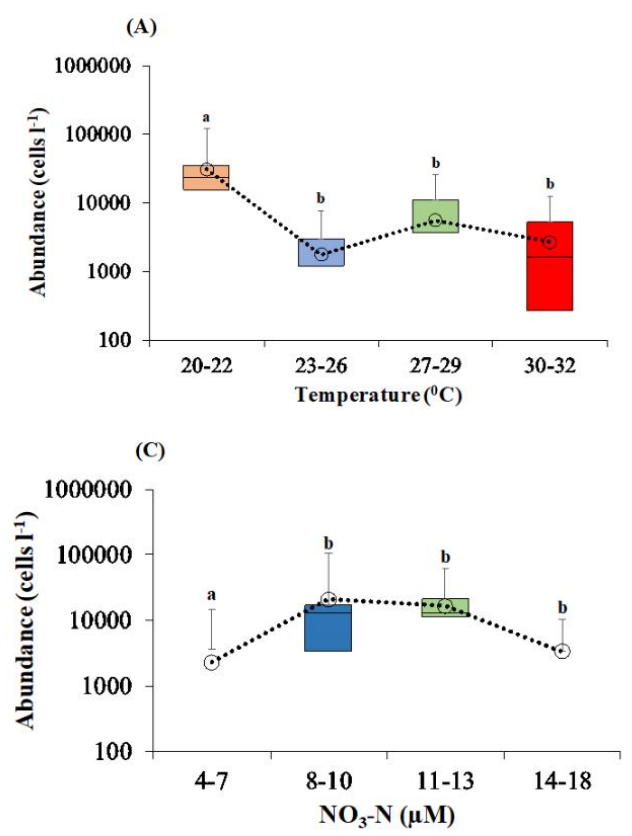

wide range of salinity tolerance. There was no significant difference among different ranges of salinity (Fig. 4B). Comparatively higher abundances of $P$. divergens were observed at nitrate-nitrogen range of $8-10 \mu \mathrm{M}\left(21.08 \times 10^{3} \pm\right.$ $27.14 \times 10^{3}$ cells $\left.^{-1}\right)$ and $11-13 \mu \mathrm{M}\left(16.67 \times 10^{3} \pm\right.$

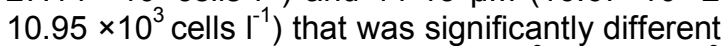
from lower values of $4-7 \mu \mathrm{M}\left(2.3 \times 10^{3} \pm 3.55 \times 10^{3}\right.$ cells $I^{-1}, p=0.022$ ) (Fig. $4 \mathrm{C}$ ). In the Maheshkhali channel, $P$. divergens preferred comparatively higher concentration of phosphate-phosphorus (31-37 $\mu \mathrm{M})$ that was significantly different from lower values of $3-12 \mu \mathrm{M}(p=0.014)$ and $13-30 \mu \mathrm{M}$ $(p=0.036)$ (Fig. 4D).

In principal component analysis, the first and second axis explained $53.8 \%$ and $28.1 \%$ of total variance in environmental parameters, diatom and $P$. divergens, respectively (Fig. 5). Protoperidinium divergens, diatom and phosphate-phosphorus were negatively related with the first axis, while salinity was positively related with the first axis (Fig. 5). Temperature and nitrate-nitrogen were negatively related with the second axis. The stepwise multiple regression demonstrated that $P$. divergens were significantly negatively and positively related with temperature and phosphate-phosphorus, respectively (Table 1 ).

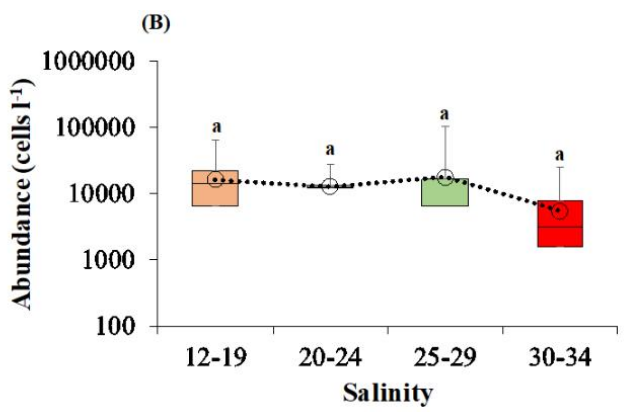

(D)

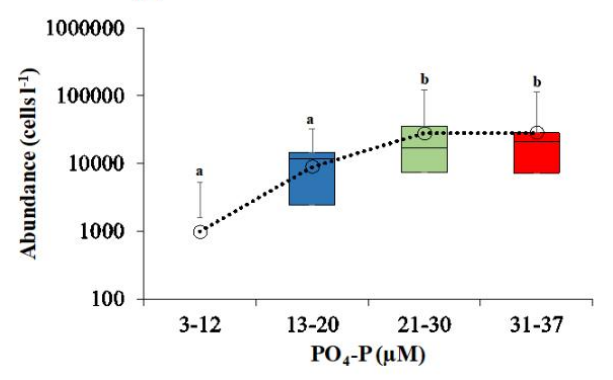

Fig. 4. Box and whisker plots showing Protoperidinium divergens abundance under different range of environmental parameters such as (A) temperature, (B) salinity, (C) nitrate-nitrogen and (D) phosphate-phosphorus. Different letters (a,b,c,d) showed significant difference between groups, analyzed by one-way ANOVA with least significant difference at significance level $p=.05$ 


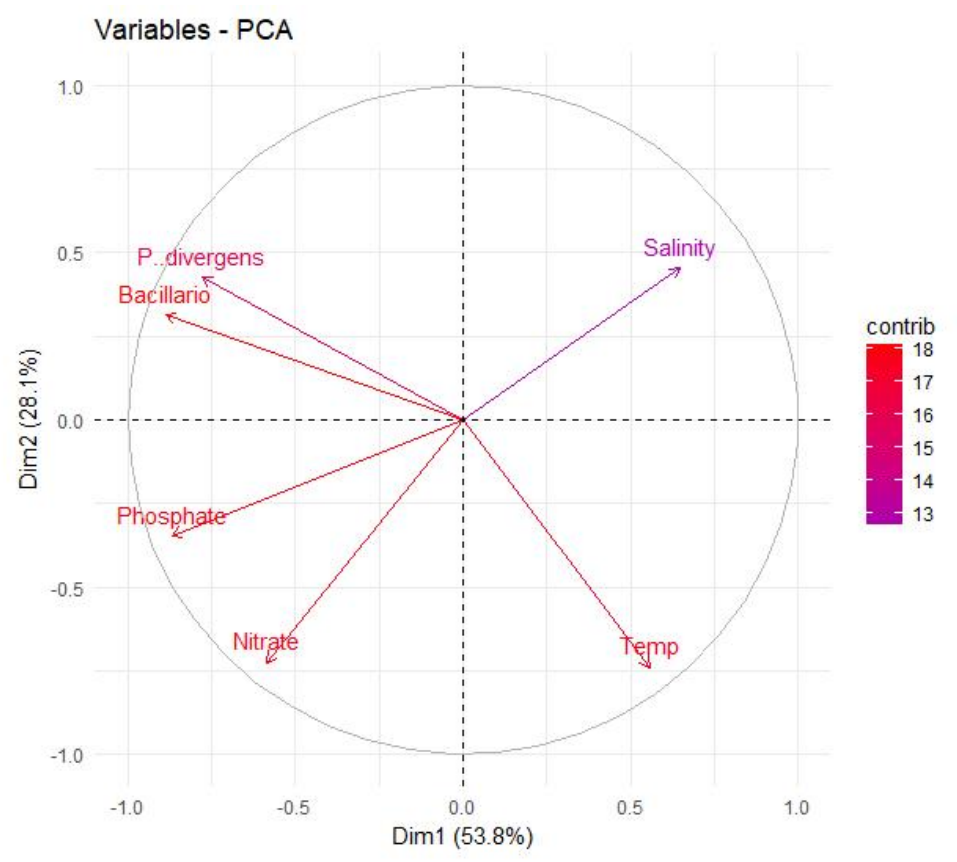

Fig. 5. A principal component analysis (PCA) of the environmental parameters, diatom and Protoperidinium divergens in the Maheshkhali channel

Table 1. Significant relationship between Protoperidinium divergens and environmental parameters as determined by step-wise multiple regression

\begin{tabular}{llll}
\hline $\mathbf{R}^{\mathbf{2}}=\mathbf{0 . 5 7 1} \mathbf{d f}=\mathbf{3 5}$ & Standardized Coeff. & $\mathbf{T}$ & Sign. \\
\hline Temperature & -0.555 & -4.778 & 0.000 \\
Phosphate-phosphorus & 0.420 & 3.618 & 0.001 \\
\hline
\end{tabular}

\subsection{Discussion}

\subsubsection{Predator-prey relationship}

Generally, diverse heterotrophic feeding mechanisms support Protoperidinium species to maintain the static population in diverse environmental and regional conditions [19]. Consistent with previous studies [4,20], diatom was the most important prey for Protoperidinium divergens in the Maheshkhali channel where higher abundance of $P$. divergens was observed concurrently with higher abundance of diatoms (Fig. 2). In principal component analysis (PCA), $P$. divergens was strongly significantly related with abundances of diatom (Fig. 5). Similarly, in the northern part of the Bay of Bengal, Protoperidinium abundance mostly depends on diatom population [12]. Protoperidinium spp. mostly prey on diatom species such as Skeletonema costatum, Leptocylindrus danicus, Thalassiosira sp., Ditylum brightwellii [21]. It is noted here that, higher abundance of
Skeletonema costatum, Leptocylindrus danicus, Thalassiosira sp. were found in the Maheshkhali channel during post-monsoon [13]. In contrast, $P$. divergens sometimes ingest dinoflagellates Gymnodinium sanguineum and Gonyaulax polyedra [22]. This contrast features might be due to inter-species and inter-regional differences.

\subsubsection{Environmental factors and abundance of Protoperidinium divergens}

In this study, Protoperidinium divergens preferred comparatively lower temperature $\left(20-22^{\circ} \mathrm{C}\right.$ ) (Fig. 4A, Table 1). In the previous studies, Protoperidinium blooms were observed at $29^{\circ} \mathrm{C}$ in the west coast of the Bay of Bengal [10] and from $21.36-29.0^{\circ} \mathrm{C}$ in Scandinavian countries [23]. Heterotrophic dinoflagellates, generally, can be indirectly stimulated by water temperature, mediated through an increase in the abundance of algal prey that may be directly stimulated by specific environmental parameters. In this study, 
the prey diatom species generally thrive in cold, turbulent and nutrient-rich environment $[24,25,26]$. It is attributed that comparatively lower abundances of $P$. divergens observed when temperature exceeded $>23^{\circ} \mathrm{C}$ (Fig. 4A, Table 1). Consistently, heterotrophic dinoflagellates (i.e. Noctiluca scintillans) sometimes cannot tolerate higher temperature $\left(>27^{\circ} \mathrm{C}\right)$, where diatom may be the most important prey items [27].

In this study, Protoperidinium divergens had no significant relationship with salinity and showed slightly higher abundance at salinity range from 25-29 (Fig. 4B). Consistently, higher abundance of mixotrophic and heterotrophic dinoflagellates were observed at salinity range from 25-27 in the Maheshkhali channel [13]. However, Protoperidinium divergens preferred comparatively higher salinity such as 31-32.6 in Andaman Sea [11] and 29 in the west coast of the Bay of Bengal [10]. Alkawri and Ramaiah [28] observed heterotrophic and mixotrophic dinoflagellates in the coast of Goa (west coast of the Bay of Bengal) over wide ranges of water temperatures, salinities and nutrient concentrations. This could be attributed to the fact that their active swimming-cell stages can adapt to the ecological variations $[18,29]$.

Protoperidinium divergens cell abundances were significantly positively related with phosphatephosphorus and had no significant relationship with nitrate-nitrogen (Fig. 4C, D; Table 1). Consistently, heterotrophic and mixotrophic dinoflagellates in the south-western coastal waters (Zurai estuary) of the Bay of Bengal were found during monsoon period when estuaries were rich in inorganic phosphate [30]. The sources of phosphate in the Maheshkhali channel are mostly from the large number of tributaries, industrial effluents, and shrimp and bivalve farm wastes. In contrast, Protoperidinium blooms off the west coast of the Bay of Bengal had been reported when nitrate was below the detectable range while the concentrations of phosphate and silicate were also low (0.245 and $1.68 \mu \mathrm{m} \mathrm{L} \mathrm{L}^{-1}$, respectively) [10]. Remarkably, comparatively lower abundances of $P$. divergens were recorded during the highest concentration of nitrate and phosphate in August (Fig. 3C, D) and it might be due to (1) comparatively lower abundance of the prey diatom species and (2) non-suitable environmental parameter such as higher water temperature $\left(>23^{\circ} \mathrm{C}\right)$. In general, nutrient can affect indirectly heterotrophic dinoflagellates (i.e. Pftiesteria spp., Karlodinium veneficum, etc.), mediated through an increase in the abundance of algal prey that may be directly stimulated by specific nutrient forms $[31,32,33]$.

\section{CONCLUSION}

For the first time, this study showed the detail documents on the bloom of Protoperidinium divergens in the Maheshkhali channel. It is attributed that the abundance of $P$. divergens are mainly controlled by the availability of the prey items in the context of tolerance of environmental parameters. For instance, along with the prey diatoms, higher abundances of $P$. divergens were favoured by comparatively lower water temperature and higher concentration of phosphate-phosphorus. In contrast, the decreased abundance of $P$. divergens was due to lower abundance of the prey diatoms and higher water temperature $\left(>23^{\circ} \mathrm{C}\right)$. Further research is needed to know the heterotrophic dinoflagellates community composition and their effects on food web structure in the Maheshkhali channel, Bay of Bengal, Bangladesh.

\section{ACKNOWLEDGEMENTS}

The research was supported by a grant from the Ministry of Science and Technology, Government of the People's Republic of Bangladesh, which is gratefully acknowledged.

\section{COMPETING INTERESTS}

Authors have declared that no competing interests exist.

\section{REFERENCES}

1. Sherr EB, Sherr BF. Role of microbes in pelagic food webs: A revised concept. Limnol Oceanogr. 1988;33:1225-1227.

2. Verity PG, Paffenhofer GA. On assessment of prey ingestion by copepods. J Plankton Res. 1996;18:17671779.

3. Jeong HJ. The ecological roles of heterotrophic dinoflagellates in marine planktonic community. J Eukaryot Microbiol. 1999;46:390-396.

4. Jacobson DM, Anderson DM. Thecate heterotrophic dinoflagellates feeding behavior and mechanisms. J Phycol. 1986;22:249-258. 
5. Gaines G, Elbrachter M. Heterotrophic nutrition. In: Taylor FJR (Ed.) The Biology of Dinoflagellates. Black-well, Oxford. 1987;224-258.

6. Hansen PJ. Dinophysis- planktonic dinoflagellate genus which can act both as a prey and a predator of a ciliate. Mar Ecol Prog Ser. 1991;69:201-204.

7. Naustvoll LJ. Prey size spectra and food preferences in thecate heterotrophic dinoflagellates. Phycologia. 2000;39:187198.

8. Jeong HJ. Predation by the heterotrophic dinoflagellate Protoperidinium cf. divergens on copepod eggs and early naupliar stages. Mar Ecol Prog Ser. 1994;114(3):203-208.

9. Gaines G, Taylor FJR. Extracellular digestion in marine dinoflagellates. $J$ Plankton Res. 1984;6:1057-1061.

10. Sanilkumar MG, Thomas AM, Shyamkumar S, Philip R, Mohammed Hatha AA, Sanjeevan VN, Saramma AV. First report of Protoperidinium bloom from Indian waters. Harmful Algae News. 2009;39:15.

11. Jyothibabu R, Madhu NV, Maheswaran PA, Nair KKC, Venugopal P, Balasubramanian T. Dominance of dinoflagellates in microzooplankton community in the oceanic regions of the Bay of Bengal and the Andaman Sea. Curr Sci. 2003;84(4):1247-1253.

12. Narale DD. Studies on ecology of cyst forming dinoflagellates from the Northern Indian ocean. PhD Thesis, Goa University, India. 2016;252.

13. Jewel MA, Haque MM, Haq MS, Khan S. Seasonal dynamics of phytoplankton in relation to environmental factors in the Maheshkhali channel, Cox's Bazar, Bangladesh. Bangladesh J Fish Res. 2002;6:173-181.

14. Sournia A, (Ed.). Phytoplankton manual: Monographs on oceanographic methodology. UNESCO Paris. 1978;6:1337.

15. Jewel MA, Khan S, Haque MM. Seasonal dynamics in the occurrence and abundance of Pseudo-nitzschia species in the Maheshkhali channel of the Bay of Bengal, Bangladesh. Bangladesh J Fish Res. 2005;9:169-174.

16. Newell GE, Newell RC. Marine plankton. London: Hutchinson and Co. Ltd.; 1977.

17. Taylor FJ, Fukuyo Y, Larsen J. Taxonomy of harmful dinoflagellates. In: Hallegraeff
GM, Anderson DM, Cembella AD, (Eds). Manual of harmful marine microalgae. IOC Manuals and Guides No. 33. Paris: UNESCO. 1995;283-309.

18. Steidinger KA, Tangen $\mathrm{K}$. Dinoflagellate. In: Tomas CR, (Ed.). Identifying Marine Phytoplankton. San Diego: Academic Press; 1977.

19. Gribble KE, Nolan G, Anderson DM. Biodiversity, biogeography and potential trophic impact of Protoperidinium spp. (Dinophyceae) off the southwestern coast of Ireland. J Plankton Res. 2007;29(11):931-947.

20. Buskey EJ, Strom S, Coulter C. Bioluminescence of heterotrophic dinoflagellates from Texas coastal waters. J Exp Mar Biol Ecol. 1992;159:37-49.

21. Jeong $\mathrm{HJ}$, Yoo YD, Kim JS, Seong KA, Kang NS, Kim TH. Growth, feeding and ecological roles of the mixotrophic and heterotrophic dinoflagellates in marine planktonic food webs. J Ocean Sci. 2010;45(2):65-91.

22. Jeong HJ, Latz Ml. Growth and grazing rates of the heterotrophic dinoflagellates Protoperidinium spp. on red tide dinoflagellates. Mar Ecol Prog Ser. 1994;106:173-185.

23. Gul S, Nawaz MF. The dinoflagellate genera Protoperidinium and Podolampas from Pakistan's shelf and deep sea vicinity (North Arabian Sea). Turk J Fish Aquat Sc. 2014;14:91-100.

24. Margalef R. Life-forms of phytoplankton as survival alternatives in an unstable environment. Oceanol Acta. 1978;1:493509.

25. Li WKW. Macroecolgical patterns of phytoplankton in the northwestern North Atlantic Ocean. Nature. 2002;419:154-157.

26. Li WKW. From cytometry to macroecology: A quarter century quest in microbial oceanography. Aquat Microb Ecol. 2009;57:239-251.

27. Tsai SF, Wu LY, Chou WC, Chiang KP. The dynamics of a dominant dinoflagellate, Noctiluca scintillans, in the subtropical coastal waters of the Matsu archipelago. Mar Pollut Bull. 2018;147:553-558.

28. Alkawri AAS, Ramaiah N. Spatio-temporal variability of dinoflagellate assemblages in different salinity regimes in the west coast of India. Harmful Algae. 2010;9:153-162.

29. Dodge JD. Marine dinoflagellates of the British Isles. Her Majesty's Stationary Office, London, England; 1985. 
30. Pednekar SM, Matondkar SGP, Kerkar V. Spatiotemporal distribution of harmful algal flora in the tropical estuarine complex of Goa, India. Sci World J. 2012;1-11.

DOI: 10.1100/2012/596276

31. Burkholder JM, Glasgow Jr HB, DeamerMelia NJ, Springer J, Parrow MW, Zhang $C$, Cancellieri P. Species of the toxic Pfiesteria complex, and the importance of functional type in data interpretations. Environ Health Perspect. 2001;109:667679.
32. Glibert PM, Burkholder JM, Parrow MW, Lewitus AJ, Gustafson DE. Direct uptake of nitrogen by Pfiesteria piscicida and Pfiesteria shumwayae, and nitrogen nutritional preferences. Harmful Algae. 2006;5:380-394.

33. Adolf JE, Bachvaroff T, Place AR. Cryptophyte abundance drives blooms of mixotrophic harmful algae: A hypothesis based on Karlodinium veneficum as a model system. Harmful Algae. 2008;8:119128.

(c) 2019 Khan et al.; This is an Open Access article distributed under the terms of the Creative Commons Attribution License (http://creativecommons.org/licenses/by/4.0), which permits unrestricted use, distribution, and reproduction in any medium, provided the original work is properly cited.

Peer-review history:

The peer review history for this paper can be accessed here: http://www.sdiarticle4.com/review-history/53054 